\title{
Contemporary Young Byelorussian Poets (1967-1975)
}

\author{
BY
}

\section{SHIRIN AKINER}

Poetry enjoys considerable popularity in Byelorussia today. Much is being written and the overall standard is remarkably high. In 1967 a new series was started, Pieršaja kniha paeta (Poet's first book), ${ }^{1}$ which, as its title suggests, was devoted to publishing the first collections of poems by individual poets. Since then, the work of nearly fifty young poets, aged between twenty-five and thirty-five, has appeared in this enterprising series. Many of them have gone on to produce second and third collections. The interest which greets them and the comparative ease with which they can have their work printed, even while still at school, ${ }^{2}$ create a beneficial atmosphere in which to develop their talents. It is small wonder that, as Nil Hilevič succinctly expressed it, poets in Byelorussia today 'rastuć, jak hryby paśla daždžu' (are growing like mushrooms after rain). ${ }^{3}$

The unifying element in their work is a deep love of their native land. The critic M. Barstok defined it thus: 'Biełaruś była i zastajecca asnoŭnym abjektam, hałaŭnym pradmietam našaj paezii' (Byelorussia was and still remains the basic object and the chief theme of our poetry). ${ }^{+}$This is no exaggeration. Byelorussia, both as a physical entity and as an emotional concept, lies at the heart of their poetic inspiration. As Nina Sklarava writes:

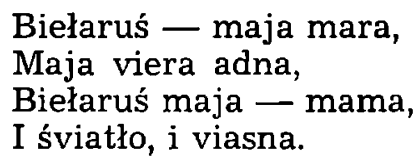

1. Material for the present article has been drawn from this series.

2. Several journals such as Maładośc, Polymia etc., regularly publish the work of young poets. In addition, collections of poems by school-children and students appear quite frequently. See for example Ch. Žyčka, ed., Naš rodny kraj. Tvorčaść pijanieraŭ i školnikaŭ respubliki, Minsk, 1959; A. Łojka, ed., Uzlot. Vieršy studentaŭ bietaruskaha dziaržaŭnaha univiersiteta imia U. I. Lenina, Minsk, 1965; A. Łojka, ed., Natchnieńnie. Vieršy maładych paetaŭ-studentă̆ BDU imia U. I. Lenina, Minsk, 1967; L. F. Tamašova, ed., Vačami dziaciej. Zbornik dziciačaj tvorčaści, Minsk, 1968.

3. N. Hilevič, 'Radasnyja nadziei. Dumki ab paezii maładych', Litaratura $i$ mastactva, 34, April 26, 1966, p. 1.

4. M. M. Barstok, Adzinstva i raznastajnaść sučasnaj biełaruskaj paezii, Minsk, 1973, p. 65. 
(Byelorussia - you are my dream, / My one faith, / My Byelorussia - you are mother / And light, and spring.) ${ }^{5}$

Or again, Volha Ipatava:

Biełaruś, tvaja dačka ja.

Ziarniatka ja, a ty - maja ralla.

Jakoj ža movy ad mianie čakaješ

Ty, uzraściǔšaja mianie ziamla?

(Byelorussia, I am your daughter. / I am a seed - you my field. / What language do you expect from me / You, the earth that nurtured me? ${ }^{6}$ The use of the mother-image to represent the native land is frequently encountered. It is a traditional concept, but it gains new strength from the fact that, for these poets, their country is quite literally a life-giving force. Without it, life would be unthinkable. As Ivan Markievič puts it:

Mnie biez ciabie žyć niemahčyma, Jak dniu viasnovamu biez sonca.

(Without you I cannot live,/ As a spring day cannot live without sunshine.) ${ }^{7}$ With greater or lesser artistry, they all echo this sentiment. It permeates everything they write, the product of an overwhelming sense of identification with the destiny of their people. (See, for example, poem three in appendix.)

Closely allied to this love of their country is pride in their native language. This generation grew up at a time a strong trend towards total russification was making itself felt throughout Soviet society. ${ }^{8}$ Byelorussia was in a particularly vulnerable position, due to its proximity to Russia, its comparative smallness and the fact that its language belongs to the same linguistic sub-group as Russian, the East Slavonic group. One of the most serious results of this situation, for Byelorussia, was that many school-children stopped studying Byelorussian. A teacher, writing about this a few years later, spoke of schools being struck by 'an epidemic of exemptions' from the subject and went on to comment: 'Niaǔžo mova Janki Kupały, Jakuba Kołasa, Maksima Bahdanoviča pavinna znachodzicca ŭ škole ŭ horšym stanoviščy, čym śpievy i čarčennie?' (Is it really fitting that the language of Janka Kupała, Jakub Kołas, Maksim Bahdanovič should

5. Nina Sklarava, Maja vioska, Minsk, 1971.

6. Volha Ipatava, Ranica, Minsk, 1969.

7. Ivan Markievič, Kamandziroŭka, Minsk, 1973.

8. This was a direct result of a decision taken at the Twenty-second Party Congress. See Programme of the Communist Party of the Soviet Union adopted by XXII Congress, October 31, 1961, part II, section 4 d. Publications in non-Russian languages dropped drastically during this period. In Byelorussia, the circulation of a journal as popular as Matadość dropped from 16,500 in 1957 to 6,500 in 1964. The situation has now improved and in 1975 its circulation was over 20,000. Polymia suffered a similar fate, as did all publications in Byelorussian. 
be relegated to a worse position in schools than singing or drawing?). ${ }^{9}$ This was written during the mid-sixties, by which time the situation had already improved somewhat, but it was still, even then, almost impossible to obtain copies of such major Byelorussian classics as ' $\mathrm{Na}$ rostaniach' (At the Crossroads) by Jakub Kolas. It is not surprising, in the circumstances, that some of these poets first wrote in Russian, turning only later to Byelorussian. There is a sense of wonder, of personal discovery, in their realisation that it is a literary language of power and beauty, capable of expressing the subtlest shades of meaning. It is this that gives poignancy and significance to such phrases as 'Mova maja! Moj ratunak!' (My language! You are my salvation!), ${ }^{10}$ or 'Pamru za ciabie biez jenku' (I'll die for you without a moan - see poem nine in appendix) which, on the surface, sound extravagantly sentimental.

The countryside, with its forests and fields, rivers, lakes and changing skies, is a constantly recurring theme. It is true that the less talented sometimes content themselves with rather hackneyed images (Bahdanovič's blue cornflower is scattered broadcast through several verses) and laboured descriptions, but in most cases there is a genuine freshness and beauty about these poems, born of a real love of nature and, more than that, a countryman's knowledge of it. Byelorussia is still largely an agricultural country. The majority of the population live in villages and small towns; even those who live in the cities often have their roots in the country. Few write about urban life. (There is almost an air of distrust in their attitude towards the city, several of them making the point that it is at its friendliest at night.) Jaŭhienija Janiščyc is particularly successful in communicating an intimate sense of delight in the country, as in the following poem:

Pryjedź u kraj moj cichi,

Tut prodkaŭ hałasy,

Tut biełyja buślichi

I mudryja lasy.

Chapaje na Paleśsi

I sonca i vady.

I što ni dvor - to pieśnia,

Sto vioska - to sady.

$\mathrm{Pa}$ travach śvietla-šyzych

My projdziem la raki,

Dzie myjuči bializnu,

Viaduć svajo žanki.

I budzie pieśnia śpieta

Pra ščaście i biadu,

I budzie padać leta

U hullivuju vadu.

9. B. Frejdkin, 'Piśmieńnik prychodzić u škołu', Litaratura i mastactva, 40, May 18, 1965, p. 4.

10. Nina Sklarava, op. cit. 


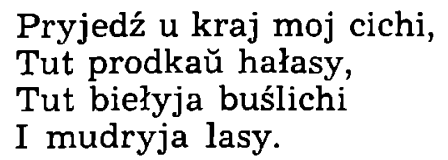

(Come to my quiet land,/ Here there are heard the voices of our forefathers,/ Here there are white storks/ And wise forests./ There is in Paleśsie/ An abundance of sun and water./ Every courtyard is a song,/ Every village - a garden./ Through the dove-grey grass/ We will walk by the river,/ Where washing their linen,/ The women gossip together./ And a song will be sung/ Of joy and of sorrow,/ And summer will fall/ Into the frolicsome water./ Come to my quiet land,/ Here there are heard the voices of our forefathers,/ Here there are white storks/ And wise forests.) ${ }^{11}$

The use of corn as a symbol of life points again to a deep attachment to the soil. It is not used as a poetic conceit, but as a familiar and integral part of daily existence. The toil of sowing and reaping is not something to be romanticized. As Viktar Hardziej puts it:

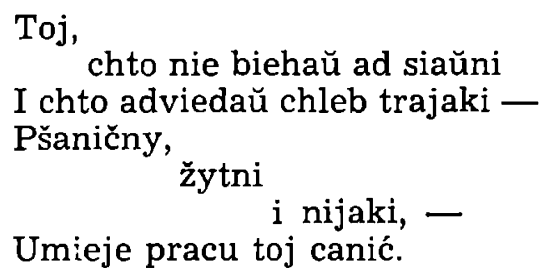

(He who hasn't shunned the sowing/ Who has eaten three sorts of bread / Wheaten, rye and none at all / He can appreciate the work involved. $)^{12}$ The importance of a good harvest is a constant concern and its final culmination in a loaf of bread, 'glowing with happiness', is the greatest blessing of all, a fitting symbol for all that is most precious in life:

\section{Skarb najvialikšy \\ i chleb na stale, \\ I kachańnie, i dzieci}

(The greatest treasures are bread on the table/ And love, and children), ${ }^{13}$ writes Hienadź Dźmitryjeŭ. The symbolic significance of corn/ bread is a familiar theme in Byelorussian literature. It still dominates the consciousness of this new generation, despite advances in mechanization.

The seasons of the year, with their attendant changes of weather, are another favourite topic. Again, they are seen from the countryman's point of view, not the townsman's. Rain is not a nuisance, hindering the daily bustle, nor an excuse for poetic melancholy. On the contrary, it is an eagerly-awaited necessity that ensures the growth of crops and even, perhaps, of humans. In the poem Varja-

11. Jauhienija Janiščyc, Sniežnyja hramnicy, Minsk, 1970.

12. Viktar Hardziej, Kasavica, Minsk, 1975.

13. Hienadź Dźmitryjeŭ, Harady na dałoniach, Minsk, 1974. 
cieli cioptyja daždžy... (The warm rains raged ...) ${ }^{14}$ Siemaškievič remembers how his mother used to urge the children to run out to play in the warm, spring rain, because it would help them to grow. Snow is also a welcome friend:

A pieršy śnieh, jak pieršaje kachańnie, Sčaśliva akrylaje, niby śmiech

(The first snow, like first love/ Gives wings of happiness, like laughter) ${ }^{15}$ writes Uładzimir Vieramiejčik.

Nature and reminiscences of village life provide the background for several poems about childhood. 'Dziacinstva załatoje' (golden childhood) is a favourite theme. It is lovingly described, radiating an atmosphere of untroubled security. There are the homely scenes of village life: dough rising in the kitchen, mushrooms frying for supper, women weaving, grandmothers gossiping. The evocative smells of childhood are faithfully recorded too: the smell of a new primer, of fresh milk, of newly-mown hay. These childhood recollections are infused with sunshine and happiness and at their centre stands the mother. She is portrayed as representing an ideal of love and tenderness, an emotional anchor even in adult life. She belongs to the earth; with her work-calloused hands, face lined and weatherbeaten, her wisdom is that of tradition, not of books. The strong emphasis on 'peasant' features points to an awareness of a certain alienation amongst the young from an older, more traditional way of life. The majority have received a college education and are now involved in intellectual rather than physical work. They might have been expected to prefer city life; instead, they look back to the village and find there the serenity and sense of purpose that seem to be lacking in modern, urbanized society.

War poems form a considerable proportion of the output of these young poets. Many of them were born during the war. Hunger and cold were no strangers then, neither were grief and desolation. The poem Nie maci $\breve{u}$ instytut pravodziła mianie (It was not mother who waved me good-bye to college - see poem five in appendix) ${ }^{16}$ by Volha Ipatava speaks of the terrible sense of loss felt by those robbed at birth of the loving warmth of a family. Too young to have known much of the fighting, they could not escape the war's legacy of misery and destruction. Hienadź Tumas is expressing the feelings of many when he writes:

Nie pomniu vajny,

Dy śniu pra jaje čamuści sny.

(I don't remember the war/ But for some reason I dream dreams about it. $)^{17}$ The forests, so much a part of the beauty of Byelorussia,

14. Ryhor Siemaškievič, Leśničoǔka, Minsk, 1968.

15. Uładzimir Vieramiejčik, Prypiać, Minsk, 1973.

16. Volha Ipatava, op. cit.

17. Hienadź Tumas, Linkos, Minsk, 1970. 
were scarred and pitted by retreating and advancing armies. They acquired a new significance as the home of the partisan opposition. The image 'partyzanski les' (partisan forest) is one that frequently recurs. Siemaškievič paints a vivid picture of the ravaged forests in the poem Ludzi kraducca pa rodnaj ziamli... (People steal through their native land...):

Ludzi kraducca pa rodnaj ziamli krok za krokam.

Tak voś było ŭ nas u tym sorak trecim

Ja ŭ Biełarusi žyvu. Miž lasoŭ maja vioska.

dalokim.

Dobra nam $z$ sosnami žyć. U susiedach

Les partyzanski. Ledź stupiš -

i zimy i viosny.

$z$ varonki snarada

Vyrviecca ptuška dy ŭ nieba niasie svaju radaść.

Sosny padbityja ŭ sercach askołki trymajuć.

(People steal through their native land step by step./ That is what it was like in far off 'forty-three./ I live in Byelorussia. Amidst the forests is my village./ We get on well with the pine trees. In neighbourly friendship in winter and spring./ Partisan forest. If you take a step - from a shell-hole/ A bird bursts forth and carries its happiness to the sky./ The shattered pines keep the splinters in their hearts.) $)^{18}$

An impressive feature of these poems about the war is their lack of bitterness. There are few expressions of hatred; instead, there is compassion and an aching sense of loss. Even those born after the war were affected by it, for signs of the physical destruction it engendered could not easily be effaced, neither could the grief of those who had lost families and friends. A poem by Janiščyc, $U$ babuli Palaniei (At Grandmother Pałanieja's), written in a folk idiom, shows a sensitive understanding of the pain of a bereaved mother:

Dal padnimuć, son raźviejuć.

Raźbiraj, łuhi, kascoǔ! -

U babuli Pałaniei

Piać asiłkaŭ-małajcoŭ.

I ŭ śpiakotu i ŭ zavieju

Kliča vulica chłapcoŭ -

U babuli Pałaniei

Piać asiłkaŭ-małajcoŭ.

Viktar, Kościa, Piecia, Dzima,

Samy mienšańki - Nazar.

.... Na pažoŭkły fotadzymak

Pakaciłasia slaza.

18. Ryhor Siemaškievič, op. cit. 
I čamu - pytać nie śmieju.

Dla babuli śviet nie mił -

U babuli Pałaniei

Piać synoŭ i piać mahił.

(The distance clears, the dream disperses./ Choose your hay-makers, meadows! - / Grandmother Pałanieja/ Has five fine fellows./ In heat and snow/ The open air summons the boys -/Grandmother Pałanieja/ Has five fine fellows./ Viktar, Kościa, Piecia, Dzima,/ The youngest Nazar./ . . On to the yellowed snapshot/ Fell a tear./ And why - I dare not ask./ The world is cold to Grandmother - / Grandmother Pałanieja/ Has five sons and five graves.) ${ }^{19}$

The main preoccupation of these young writers is undoubtedly their native land. When they are not writing directly about it, they are using it as a source of imagery. Modern technological achievements interest them little. A poem by Siemaškievič, Za liŭnami, za arkami viasiołak... (Beyond the rains, beyond the rainbow's bounty... - see poem two in appendix), ${ }^{20}$ sums up their feelings very well: fly to the planets if you must, but there are marvels enough for us here on earth, amidst our own forests and streams. Some, such as Vieramiejčik, feel even more strongly about it:

Ludzi! Caho lecicio vy u kosmas,

Sto vy šukajecie tam?

Kłali b la rečak ziamnyja prakosy,

K śpiełym chadzili žytam.

Ludzi! Navošta jana vam - Vieniera?

Źziaje niachaj miž niabos!

Moža, ŭzłamaŭšy niabiesnyja dźviery,

Zojducca sercy ad śloz.

(People! Why are you flying to the stars,/ What are you seeking there?/ 'Twere better to cut swathes along the river,/ And to betake yourselves to the ripe fields of rye./ People! What is she to you Venus?/ Let her shine amidst the heavens!/ Perhaps, having broken down the gates of space,/ Hearts will die with tears. ${ }^{21}$ The history of their country provides inspiration for some poets. Leanid Dajnieka ${ }^{22}$ has written some excellent poems on this theme. He and Aleś Razanaŭ ${ }^{23}$ both show a concern for man's role in society, which gives their work a notably philosophic bias. For the most part, however, there is little interest in questions concerning mankind as a whole.

19. Jauhienija Janiščyc, op cit.

20. Ryhor Siemaškievič, op. cit.

21. Uładzimir Vieramiejcik, op. cit.

22. Leanid Dajnieka is a prolific writer. Apart from his first collection, Hałasy, Minsk, 1969, which appeared in the series Pierకaja kniha paeta, he has already published two more: Bierah čakañnia, Minsk, 1972, and Načnyja telehramy, Minsk, 1974.

23. Aleś Razanaŭ has had two collections published already: Adradžeńnie, Minsk, 1970, and Nazaŭždy, Minsk, 1974. 
The general attitude expressed in these poems is one of happiness in the present and optimism for the future.

There is a lively interest in literature. Several poets show familiarity with a wide range of works; their own work contains allusions not only to their own literary tradition, but also to that of other countries, even, in some cases, to classical literature. Naturally enough, their chief heroes are Byelorussians such as Kołas, Kupała and Bahdanovič, but amongst Russians, Lermontov, Blok and Jesenin are much admired. Jesenin in particular has had a major influence in both style and subject-matter. An interest in literature is evident, too, in the concern shown for technique. Jurka Hołub ${ }^{24}$ and Uładzimir Dziuba $^{25}$ are clearly fascinated by form. Their work is very inventive and shows a high degree of technical accomplishment. Dajnieka and Razanaŭ seem to be attracted by the epic. Mikoła Viaršynin ${ }^{26}$ continues the tradition of the satirical fable, producing amusing verses on such themes as the dangers of drink and the pitfalls of bureaucracy. Folk rhythms are arousing a certain amount of interest, but there is as much cnthusiasm for trying out new ideas as there is for adapting traditional forms. An example of the enterprising nature of some of these experiments is seen in Luboŭ Filimonava's attempt, in the poem Sanata Curlonisa (Curlionis' Sonata), ${ }^{27}$ to combine verse and prose in a form derived from music.

Despite the fact that the majority of these poets are men (the ratio is about four to one), many of the best known are women. Jaŭhienija Janiščyc (b. 1948, Brest region) is probably the most popular of all. She began writing while still at school and achieved almost instant success. Her poetry has been translated into several languages, including German. Her work has an appealing spontaneity. Happiness wells up from inside and bubbles over into everything she writes. Most of her poems are inspired by her love for her country, its language, traditions and natural beauty. At first sight her work seems simple, but this simplicity is the product of a remarkable poetic gift. There is a precision in her use of words and images and a tautness of style that is highly professional. A typical example of her disciplined approach is found in the poem $D a$ sustrečy (Au revoir). This poem, first published in 1968 in a children's collection, ${ }^{28}$ originally contained the lines:

\section{Chodzić sonca pa zareččy \\ Močyć kosy u vadzie. \\ Nad vadoju dźvie viarbiny - \\ Dźvie žurbotnyja siastry.}

24. Jurka Hołub has also had two collections published: Hrom na zialonaje holle, Minsk, 1969, and Dreva navalnicy, Minsk, 1973.

25. Uładzimir Dziuba, Vulicy biez nazvaū, Minsk, 1972.

26. Mikoła Viaršynin, Biez viny vinavatyja, Minsk, 1972.

27. Luboŭ Filimonava, Stazvony, Minsk, 1974.

28. L. F. Tamašova, ed., Vačami dziaciej. Zbornik dziciačaj tvorčaści, Minsk, 1968. Jauhienija Janišcyc has now brought out a second collection: Dzień viečarovy, Minsk, 1974. 
(The sun is passing by on the far side of the river/ Washing its braids in the water./ Above the water are two willows - / Two sad sisters.) In the later version which appeared in the series Pieršaja kniha paeta, the second line had been changed to 'Pa kaleni $u$ vadzie' (Up to its knees in water), a sharper, more precise image. Similarly, the vague 'vadoju' (water) of the third line was replaced by the more exact 'rakoju' (river). Her poems sparkle with the blues, greens, golds and rusts of the countryside. Added to this visual element, her work has an intricate acoustical structure. Alive to the emotional effects of rhyme and assonance, she has a particular fondness for repetitions and echoes. This, linked to a strong rhythmic sense, generates the crispness and energy that are so characteristic of her style.

Volha Ipatava (b. 1945, Hrodna region) is in some ways the antithesis of Janiščyc, for she is as much an introvert as the other is an extrovert. Their themes are similar, but their styles very different. Ipatava's verse has a calmer, more reflective quality. Her images, though born of the countryside, are touched with a dreamlike fantasy, as, for example, in the poem Ranica (Morning):

\section{Aduvančyk vializny - sonca \\ Vyrastaje $z$ prycichłaj raki. \\ Tumany, jak miadźviedzi kałmatyja, Dapaŭzajuć da lesu kradkom.}

(An enormous dandelion - the sun/ Grows out of the silent river/ ... Clouds, like shaggy bears/ Creep stealthily upon the forest. ${ }^{29}$ A war-orphan, much of her work is permeated with a sense of inner loneliness. The need for maternal love finds sublimation to some extent in the passionate love for her country that dominates her whole being.

Maryja Saŭčonak (b. 1944, Mahiloŭ region) ${ }^{30}$ and Ludmiła Zabałockaja (b. 1950, Mahiloŭ region) ${ }^{31}$ write poetry of a mainly intimate nature (see poems four and seven in appendix). The love poetry of many of these young poets is banal. Saŭčonak, however, writes with sensitivity and a striking sophistication of expression, reminiscent, at times, of Anna Achmatova. Like Achmatova, she is able to write of the pain of love, of love rejected and love coming to an end. Zabałockaja, too, chooses themes of a personal nature. Much of her work is tinged with an air of adolescent melancholy, in marked contrast to the confident optimism of the majority of her contemporaries.

Hienadź Paškoŭ (b. 1948, Viciebsk region) ${ }^{32}$ writes with an impeccable sense of style. An outstanding quality of his verse is the beauty and subtlety of its language. This is achieved not merely by creating effective images, but rather by a special awareness of

29. Volha Ipatava, op. cit. She has produced two more collections: Lipieńskija navalnicy, Minsk, 1973, and Parastki Minsk, 1976.

30. Maryja Saŭconak, Biełaja łastaŭka, Minsk, 1971.

31. Ludmiła Zabałockaja, Sakavik, Minsk, 1974.

32. Hienadź Paškoŭ, Klanovik, Minsk, 1975. 
the language itself, of the acoustical properties and emotional weight of each word (see poem three in appendix).

Valancina Koŭtun (b. 1946, Homiel region) is most at home in nature lyrics. Her observation is exact and many of her descriptions are drawn with great delicacy. She is a fine poet. The poem Liście (Leaves - see poem eight in appendix) ${ }^{3.3}$ is an example of the characteristic skill with which she handles a theme, here the theme of re-birth, beautifully matching the structure of the poem to its content to create a harmonious whole.

Ryhor Siemaškievič (b. 1945, Minsk region) stands in a class by himself. He is a poet of a maturity and an objectivity that set him apart from his fellows. Like them, he writes about his native land. Unlike them, he uses it as a liberating force. For many, the act of writing about their country is an end in itself: having described it, having written of their love for it, there is little more to say. The total effect of their work, consequently, is monotonous, even though individual poems are often very good. Siemaškievič instinctively understands that his country is an inalienable part of his being. It might almost be said to represent the sum of his experience,for it has made him what he is, shaped his thoughts and given him a language in which to express them. It furnishes him with a poetic base on which to build a congenial and coherent imagery through which to express his feelings, his beliefs, his comments on human nature. He writes about his country in a natural, unconstrained manner, seeing it less as his country than as his experience of the world. As a result, his poetry has a universality that is lacking in that of his contemporaries. This does not preclude him from giving his poems a precise physical setting when necessary. The poem Za liŭnami, za arkami viasiolak... (see poem two in appendix), for example, expresses an idea that has general validity, but it is given a definite location. (The names 'Mars' and 'Jupiter' are the actual names of two villages, so he is able to use them for a witty play on words.) Throughout his work there is apparent the firm conviction that a poet is a thinker, not a camera, that he is involved in life and that more is required of him than that he merely reproduce his surroundings. This sense of commitment does not result in solemn, philosophical treatises, however. He commands a wide range of expression and is as much at home in a lyric vein as in a tragic or heroic. A wealth of concrete detail prevents his poems from ever seeming to meander aimlessly in search of an 'idea'; a gentle humour saves them from any suspicion of pomposity. The lightness of his style, with its amusing, neatly observed touches, is effectively illustrated in the poem Sakavik (March):

Kali zima zdaloku jedzie

Sa śvitaj siviernych viatroŭ, Tady ŭ biarłohi ŭsie miadźviedzi Chavajucca ad marazoŭ

33. Valancina Koŭtun, Kalarovyja viosty, Minsk, 1971. 
Tam miakka, ciopła na halinach.

Jak raj ... zasunie łapu $\breve{\mathrm{u}}$ rot

Dy śnić pra śpiełyja maliny

I pra sałodki dziki miod.

(When winter comes from afar/ With its suite of northern winds,/ Then all the bears in dens/ Hide themselves from frosts./ There it is soft, warm on the twigs./ Like heaven... He sticks his paw into his mouth/ And dreams of ripe raspberries/ And sweet wild honey.) $)^{34}$ Trees are his special love; he feels a deep affinity with them and frequently apostrophizes them. He is in his element in the forest, 'hulki raj, dzie boh adzin - laśnik' (resonant paradise, where God alone is forester) ${ }^{35}$ His love of his country and his love of nature are thus inextricably intermingled, for in feeling himself a part of one, he is inevitably a part of the other. This strong sense of kinship with nature does not dominate his work exclusively, however. His themes are varied and include such subjects as a child's painting lessons, an abandoned estate and dreams in colour. He treats his material imaginatively, bringing to it a highly personal vision of life. Not content with a superficial representation of reality, he has the ability to develop and deepen his ideas, giving them a wider significance. The poem Zokata salomy (Straw Gold - see poem one in appendix $)^{36}$ is a beautiful illustration of this.

Young Byelorussian poets today are faced with several problems. There are the problems that face all young poets: problems of finding their own 'voice' and defining their own sphere, deciding for themselves whether the poet should be society's conscience, or whether, as Dryden would have it, he should strive above all to delight. There is, too, the additional problem of trying to create a 'national' style in literature. It is not a problem that is unique to Byelorussia, but it is certainly one to which there is no easy solution. In the Soviet Union it has a special significance for all the non-Russian peoples, for the idea of a one-language society constantly hovers in the background, a potential threat to their native languages. There has been much discussion of this question in Byelorussia in recent years. Some critics maintain that content alone conveys the national characteristics of a work and that language, as the medium, is of no importance: translation preserves all that is essential. Consequently, there is no point in writing in one's own, 'minority' language; better by far to write directly in the language of the majority. ${ }^{37}$ Others refute this argument by pointing out that it is precisely language that gives a literature its individuality: 'Nacyjanalnaja śpiecyfika paezii

34. Ryhor Siemaškievič, op. cit. He has had a second collection published: Subota, Minsk, 1973.

35. Ryhor Siemaškievič, Leśničoŭka, Minsk, 1968.

36. ibid.

37. See for example V. D. Barmičev, $V$ jedinom sojuze, Minsk, 1972, pp. 192208; S. Z. Ješin, Razvitije kul'tury v BSSR, Minsk, 1970, pp. 221-9. 
vyrazna raskryvajecca praz movu, jaje płastyčnaść i mietafaryčnaść, praz idyjematyçnyja zvaroty, prymaŭki i prykazki, bo ŭ movie adbilisia i psichałahičnyja asablivaści naroda i asablivaści jaho myśleńnia i ŭsprymańnia.' (The national element in poetry vividly emerges through the language, its plasticity and range of metaphor, through idiomatic turns of phrase, sayings and expressions, for the language reflects the psychological peculiarities of a people, their peculiarities of thought and perception. $)^{38}$ The young poets have made their own position in this debate very clear. By writing in and about their language as they do, they make an unequivocal affirmation of the fact that for them, this is the only legitimate means of expression.

Unavoidably, perhaps, there is a degree of self-consciousness in their preoccupation with their country. This, in turn, has tended to restrict their thematic range. They have been criticized for writing too much about nature and too little about the world they live in, for ignoring the problems and the achievements of modern society and escaping, instead, into a rural idyll..$^{39}$ For some, the criticism is valid but the fault lies less with the choice of subject than with intellectual apathy. They feel (and it is not untypical of young poets in general) that they have done their duty, poetically speaking, by choosing an 'appropriate' theme. In poetry there can be no such short-cuts, unfortunately: it is the poet, not the subject, that makes the poem. There is nothing inherently poetic about nature; equally, war is terrible but poems about the war are not inevitably soul-searing. (This is particularly apparent when one compares the genuine emotion in the work of those who experienced the war and its tragic aftermath with the empty rhetoric of those born many years later.) These, however, are faults of immaturity. As a group, the young poets of Byelorussia show much promise and it will be interesting to see how they develop. Some of them are already poets of considerable stature. Their work deserves, and will no doubt win, wide recognition.

38. M. M. Barstok, op cit., p. 81; see also N. S. Pierkin, Nacyjanalnaje $i$ internacyjanalnaje ŭ litaratury, Minsk, 1971, pp. 144-8.

39. See Dz. Buhajoŭ, I. Kudraŭcaŭ, eds., Na stryžni času. Zbornik krytyčnych artykulaŭ, Minsk, 1973, pp. 191-203, 212-38. 
APPENDIX

Verse translations by Vera Rich

\section{ZOEATA SAEOMY}

Jak zorka žnivienia lacić — łavi, ruka!

To ziernie pieršaje zlataje $z$ kałaska.

Dni na sychod. Adbiŭ najdoŭhi čas.

Dzień zołata sałomy siońnia ŭ nas.

Pryjšli kambajny ludziam pamahčy, Chadzili cichim chodam da načy. Papłyŭ žytniovy saładkavy duch, A $z$ hniozdaŭ pierapiołak - šery puch.

Chadziem, mały! Hladzi, usie pajšli, Ziamnoha ščaścia viazki paniaśli.

Tak! Kožny rupicca, daŭno pryvyk Nabić sałomaj śviežaju siańnik.

Jak dobra śpicca ... Spać kudy lahčej, $\mathrm{Nu}$, nie raspluščyć ranicaj vačej.

Sałoma žytam tolki što była, Jana jašče raście, nie darasła.

Jana pachuča soncam addaje, I vołkaść adčuvajecca jaje.

Laž, chłopčyk, na śviatuju čyściniu Ty ž sam, jak čyścinia jaje ahniu.

Ja ž u dychańni soniečnym zamru, Prad zołatam jaje pierabiaru Nanova kožny dzień žyćcia, što źnik.

Voś tak pierabiraje katalik

Ružaniec viečarami $u$ cišy

Ci sknara hrošy - ščaście dla dušy.

Sto ž, kožnamu svajo - jaki tut ździŭ? Ja ž zołata takoje palubiŭ, Ahon kastra, vadu, udar viasła.

Sałoma siońnia da mianie pryjšła.

I pokul vodar hety nie ačach, Pakajusia va ŭsich svaich hrachach.

A potym budu błasłaviona spać.

Jak dziŭna! Zołata, a nie kuplać.

I tolki załatyja sny adny,

Pryśniacca ludziam załatyja sny. 
Za liŭniami, za arkami viasiołak, U krai piesień i junačych mar Jupiter - na Dziaržynčynie pasiołak, Na cichaj Žłobinščynie - vioska Mars.

Tam da upadu viečarami polki, Nie śpicca tam udovam pa načach. A cišyni prazrystaj, zvonkaj kolki, Błakitu cichaha ŭ davierlivych vačach!

A niedzie na vialikich kasmadromach Stajać na starcie vyrai rakiet, A niedzie dniom i nočču astranomy Cikujuć za arbitami płaniet.

Prajścisia b im, spakojnym, mudrym, hroznym, Kala svaich biaroz, svaich busłoŭ

Da vioski Mars pa sinich-sinich rosach, Da tajamnicy - rek, lesavikoŭ.

Turysty pa praspiektach, pa vakzałach ...

Płanieta Mars zahadkaju maǔčyć ...

A u vioscy Mars ihrajuć na cymbałach

I niemaŭlaty vučacca chadzić.

Uzlatajem, ludzi, rviomsia my za chmary.

Niachaj startujuć našy karabli!

Nie zabyvajcie ž pra ziamnyja Marsy

I nieziamnyja cudy na Ziamli.

Ryhor SIEMASKIEVIC

3

Ziamla,

dziadoŭ maich ziamla, pryznańnie heta

nie dla klatvy.

Ty ruki mnie

pieraplała

tryputnikam

i dzikaj miataj.

Da kožnaj tkanački

ja tvoj.

Tvoj bol - moj bol,

suchmień ci livień.

Prašu ciabie, ziamla,

dazvol

być kałaskom

u rodnaj nivie. 
Nam zdałosia:

Siarod ich

słovy - prosta huki.

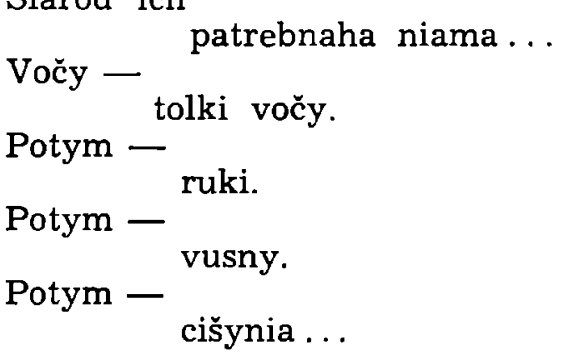

Nie maci ŭ instytut pravodziła mianie, Zrabiǔšysia ad ščaścia maładoj.

Uzrušana ŭ toj viečar zaźvinieŭ

Kala vahona ŭvieś dziciačy dom.

Ravieśniki ...

Skroź viosienskaje škło,

Jak praz sady, hladžu na ich $z$ akna:

Nie vierycca, što matčyna ciapło

$\mathrm{Z}$ dziacinstva adabrała ŭ nas vajna.

Nie znajem my, kala jakich biaroz

U horkim dymie hinuli baćki.

Ale naviek adzin źviazaŭ nas los, Jak nitkaju hrybnoj baraviki.

Nie maci ŭ instytut pravodziła mianie...

Volha IPATAVA 
Ty paklič mianie. Pazavi.

Tam zabłudzimsia ŭ chmielnych travach.

Pačynajecca ŭsio z lubvi,

Navat samaja prostaja java.

I tady dušoj nie kryvi

$\mathrm{Na}$ darozie žyćcia šyrokaj.

Pačynajecca ŭsio z lubvi -

Pieršy pośpiech i pieršyja kroki.

Pryručajucca sałaŭi

Tam, dzie vybiehli ŭdal kanavy.

Pačynajecca ŭsio $z$ lubvi -

Adčužeńnie i bol, i nianaviść.

Ty paklič mianie. Pazavi.

Sto daroh za maimi plačyma.

Pačynajecca ŭsio $z$ lubvi,

A inakš i žyć niemahčyma.

Zurbotna vyklakotvali busły,

I poŭniłasia ranicaju vioska ...

I čovien zabłudziŭsia moj i viosły.

Dziacinstva prapłyvali karabli.

Stupić na ich $-\mathrm{z}$ dubovaje kary.

I z parusam adbyć. A dzie toj parus?

Karabliki - dziacinstva majho mary,

Płyvuć jašče da hetaje pary.

I ty adzin.

I ja adna zusim.

Karablik svoj dasiul ja zachavała.

I ja ǔžo na darosłym pieravale

Busłoŭ dziacinstva čuju hałasy.

Ludmiła ZABA£OCKAJA 
Viasnoju rańniaj $\mathrm{z}$ cichim śmiecham

Raście śviatło ŭ dušy majoj.

Abnoŭlenaja, paśla śniehu -

Voś tak balić ziamla travoj:

Voś tak raście ściabło biez kryku,

Daždžy ščyrujuć ad vidna.

A ptuški ǔžo adčuli kryły,

I viecier chmary razahnaŭ ...

Chaciełasia u słovach vyjście

Znajści,

Skazać ...

Dy spakvala

Tryvožna z dreŭ vychodzić liście, -

I radasna zmaŭkaju ja.

Valancina KOŪTUN

9

MOVA

N. S. Hileviču

Cuju tvaju žaŭrukovuju muzyku

U skošanych travach murožnych.

Mova! Jak sonca majo

$$
\text { biełaruskaje, }
$$

Ty sviecišsia słovam kožnym.

Ciabie i zavorvali i zakopvali.

I ŭsio ž našy prodki praz hora

Danieśli da nas ciabie,

$$
\text { rodnuju, ciopłuju, }
$$

Žyvuju i niepaŭtornuju.

I kali ty mianie tolki paklikaješ,

Pamru za ciabie biez jenku.

Našu ja luboŭ da ciabie

U sercy svaim maleńkim.

$$
\text { vialikuju }
$$




\section{STRAW GOLD}

Like a star of August falling - catch it, hand!

The first grain falls from the ripe ear throughout the land.

The days decline. The longest time is past.

The day of straw gold has come round at last.

The combines came to help with all their might,

Quietly about the fields they went till night.

The sweetish scent of rye drifted around,

And, drifting from the quails' nests, came grey down.

Let's go, my boy! Look, all have gone. Each holds

A bundle of earth's happiness of gold.

Yes! Each is eager, eager as of yore,

To fill his palliasse with fresh new straw.

How sweetly then you slumber, sound and deep;

Morning can hardly rouse your eyes from sleep.

The straw was growing rye till yesterday, It still is growing, has not died away.

It radiates sunlight and fragrant scent, And still its living moisture is not spent.

Lie down, boy, on its holiness, and rest For like its pure fire, you too are blest.

And I'll stand in the breathing of the sun, Before its gold tell over, one by one, Every day of my life, and shall recall Them, as a Catholic when evening falls

Quietly tells his rosary, or bent

Miser his gold, counting his heart's content.

To each his own - what wonder here unfolds? But I have found a great love for this gold, The bonfire's flame, water, a splashing oar. And so, today, there comes to me this straw.

Before its fragrant scent is past and done, I shall confess my sins here, every one.

And then I shall sleep sound in blessedness.

How strange! This gold is given as largesse.

And then our dreaming glows with golden gleams, And sleep is filled with naught but golden dreams. 
Beyond the rains, beyond the rainbow's bounty, In the land of songs and young dreams afar, Jupiter-hamlet lies in Dziaržynsk county, And in quiet Žłobyn is the village Mars.

They polka till they drop there, every evening. The widows cannot sleep a wink at night, How much transparent ringing quietness breathes there, How much quiet azure gleams in trustful sight.

Somewhere in the huge cosmodromes out yonder, Upon the launching pads the rockets swarm. Somewhere astronomers unceasing ponder The orbits that the planets move upon.

These calm, wise, awesome scholars would do better To go where native storks and birch-trees dwell, To Mars-village, where azure dewdrops glitter, To mysteries of streams and forest-elves.

Through streets and railways tourists press abounding... The planet Mars holds silent riddles still ... With cymbaloms Mars village is resounding, And infants learn to toddle with a will.

So let us fly, beyond the clouds our courses, And let us duly launch our spaceships bold, But let us not forget our earthly Marses, And the unearthly wonders that Earth holds.

Ryhor SIEMAŠKIEVIC

3

Land

of my fathers, oh my land!

This is no oath

Upon me binding.

For you have tightly

Bound my hands

With wild mint and

With clover twining.

In every fibre

I am yours,

Your grief - my grief

In drought or flowing.

Land, grant me to live

Forever more

An ear of grain

In your field growing. 
It seemed to us

Among them

that words

were noise unplanned,

Eyes were

nothing needful to be found...

And then

only eyes.

came hands.

And then

And then

came lips.

came quiet profound...

Maryja SAŬCONAK

5

It was not Mother who waved me goodbye

To college, young again with happiness.

Ringing with excitement they all pressed

About the carriage, the whole orphanage.

All of my year...

out through the autumn glass

I see them as if through ranked trees I gaze:

One can't believe that war robbed our whole class

Of mother's warmth, in early childhood days.

We do not know under what birch-trees' shade

In bitter smoke our parents ceased to be.

But like dried mushrooms strung upon one thread,

One fate binds us for all eternity.

It was not Mother who waved me goodbye...

Volha IPATAVA 
Call to me, summon me, call.

We shall lose our way in heady grasses.

All things begin with love, all.

Even the least thing that passes.

Do not let your soul twist or fall,

On life's white road spreading broadly,

All things begin with love, all,

The first success, the first steps forward,

Nightingales have grown tame, where the small

Channels run out, unabating.

All things begin with love, all -

Estrangement and anguish and hating.

Call to me, summon me, call,

Ten-score roads lie behind me, most surely.

All things begin with love, all.

Or else life is beyond all enduring.

Jauhienija JANISCYC

The storks were clacking gloomily on high,

The village was filled with the morning radiance...

The boat and the oars too were lost and straying.

All of my childhood ships have floated by.

If one could step upon these oak-bark hulls

And sail away in them ... Where can the sail be?

These ships are childhood dreams that used to sail

And right down to the present time are sailing.

You are alone.

I am alone always.

Till now I kept my little ship quite safe.

Now at the turning point of adult life,

I hear stork voices from my childhood days.

Ludmiła ZABAŁOCKAJA 
Quietly smiling in the spring morning The light grows in my soul and awakes After the snow, renewed, reborn now. Thus from the grass the earth now aches. Thus grows the stem without a murmur Rains fall heavily from first light.

Birds feel new life in wings unfurling, The wind has put the clouds to flight.

To find the words I long and thirst now,

To find,

To say ...

But now the bright

Startled leaves from the trees are bursting, And I stand silent with delight.

Valancina KOUTTUN

\section{LANGUAGE}

For N. S. Hilevič

I hear your skylark music outflowing

In newly mown hay-field's fresh sweetness.

Language! You are

like our native sun glowing.

With every word you strike deeply.

They ploughed you in and buried you under.

Yet our forefathers, through anguish surviving,

Bequeathed you to us

in your unique wonder,

Warm and still living and thriving.

And whenever you call to me, straightway

I'll die for you without moan or quiver.

I carry a love for you

In this my small heart forever.

$$
\text { a great one, }
$$

